\title{
ANALYSIS OF THE DEVELOPMENT OPPORTUNITIES OF SOLAR SYSTEMS IN SERBIA
}

\author{
Jasna Tolmac ${ }^{a^{*}}$, Slavica Prvulovic ${ }^{\mathrm{a}}$, Marija Nedic ${ }^{\mathrm{a}}$, Dragisa Tolmac ${ }^{\mathrm{b}}$ \\ a Technical Faculty "Mihajlo Pupin”, University of Novi Sad, Serbia, ORCID --- \\ b Faculty of Management, University of Nikola Tesla, Belgrade, Serbia, ORCID --- \\ *Corresponding author: e-mail: jasnatolmac@yahoo.com
}

\begin{tabular}{|c|c|}
\hline ARTICLE INFO & ABSTRACT \\
\hline $\begin{array}{l}\text { Article history: } \\
\text { Received: May } 2019 \\
\text { Received in the revised form: } \\
\text { June } 2019 \\
\text { Accepted: June } 2019 \\
\end{array}$ & \multirow{2}{*}{$\begin{array}{l}\text { The paper analyzes the development opportunities of solar systems in } \\
\text { the Republic of Serbia. Renewable energy sources and their energy } \\
\text { potential, such as solar energy, should be considered in order to meet } \\
\text { the needs of consumers. Solar energy can be considered the most } \\
\text { modern renewable energy whose utility is still developing, and it is } \\
\text { not represented as the utilization of hydro energy sources. Researches } \\
\text { show that Serbia is a country with a high RES potential and that it has } \\
\text { favorable conditions for production of electrical and heat energy from } \\
\text { renewable sources. The aim of this paper is to present the possibilities } \\
\text { of using solar energy in Serbia. Energy supply from renewable energy } \\
\text { sources is a key factor for each country's strategy, because it directly } \\
\text { contributes to reducing the negative effect on the environment. }\end{array}$} \\
\hline $\begin{array}{l}\text { Key words: } \\
\text { Sun, } \\
\text { renewable energy sources (RES), } \\
\text { solar energy, } \\
\text { solar potential, } \\
\text { solar radiation }\end{array}$ & \\
\hline
\end{tabular}

\section{Introduction}

Renewable energy sources are those energy sources that do not cause pollution, and therefore they include energy of water, wind energy and energy of the Sun. Solar energy appears on Earth as the largest energy source in relation to other types of energy. It constantly renews the energy of water, wind, wave, thermal gradient in oceans and bioenergy through photosynthesis. The use of renewable energy sources contributes to more efficient use of its own potentials in energy production, reduction of greenhouse gas emissions, reduction of fossil fuel imports, development of local industry and job creation. Today available renewable energy sources are solar energy, wind energy, water energy, geothermal energy, and biomass energy.

Serbia is an energy medium-dependent country, given that the annual consumption of all types of energy is higher than domestic production, with the total import dependency of about $40 \%$.

\section{Points of the Program in the Field of Renewable Energy Sources in Serbia}

The main points of the RES program include more efficient use of own potentials in energy production, reduction of greenhouse gas emissions, reduction of imports of fossil fuels, development of local industry, opening new jobs. 
Renewable energy sources are the main backbone of Serbia's energy independence in the future. The total potential of energy from renewable sources satisfy a quarter of Serbia's annual needs (Prvulovic et al., 2009, 2016a) and when a huge potential for energy savings in all sectors is added to it, the overall impression is that Serbia has good renewable energy sources. Potentials of Solar RES in Serbia is about 0.1 tons of equivalent oil / $\mathrm{m}^{2}$ of collectors per year (Prvulovic et al., 2012, 2013).

\section{Solar energy}

Solar energy is the energy of the Sun's radiation, which we notice in the form of light and heat that we receive from the largest source of energy on Earth, the Sun. It is necessary to look at the prospects for the future application of solar energy, since it is an energy that has huge and inexhaustible potential and can be used for heating, cooling, electricity production, i.e. for many purposes and in various fields of application: households, industry, agriculture, etc. It is also necessary to look at the energy and exploitation possibilities of using solar energy in all segments of Serbia's energy consumption and to present a relevant base for making decisions for the application of these technologies to potential investors.

From the point of view of energy, solar energy represents a resource that is available for the use and substitution of significant amounts of conventional energy forms. Its limited use is caused by technological and economic problems. It is a huge energy source that can meet energy needs for a very long time. Solar energy can have a significant place in the energy of a country because it represents a renewable and inexhaustible energy resource. Renewable energy sources do not draw much attention of the world. It can be easily stated that a relatively small number of countries pay more attention to this problem, the more developed ones.

Energy technologies are based on the use of solar energy and are most developing in countries that are technologically and economically more powerful. There are several reasons for this, of which the most important are strategic, economic and ecological factors. Solar energy is, ecologically speaking, pure energy whose energy technologies do not pollute the environment. It represents a resource available to every country without import dependency.

It is especially important that solar energy installations can be built in a proximity to consumers without significant investment in infrastructure. Solar energy is simply transformed by technical means directly into heat and directly or indirectly into electricity, which enables rapid application in all energy processes. The use of solar energy in all segments of energy consumption today is in a significant increase in many countries in the world.

Solar energy provides a variety of application options. Modern solar systems allow the use of solar energy throughout the year. These systems can supply up to $35 \%$ of all needs in northern and central Europe, and 70\% in the south of Europe (Lambic, 2011; Tolmac et al., 2014a, 2014b; Markovic et al., 2009; Grbic et al., 2008). At the same time, the emission of harmful gases into the atmosphere is significantly reduced, which is an argument more for the use of solar energy.

For decades, solar energy has been used to generate heat in terms of heating water, living space, and for cooling. The use of solar energy has multiple advantages. It is a quiet, clean and reliable source of energy. Due to the rising cost of fossil fuels and the need for 
Analysis of the development...

preserving the environment, there is an increasing interest in using solar energy. In residential buildings there are two types of solar thermal energy systems: those used exclusively for water heating and those that provide heating (the so-called combined systems).

The application of solar energy can be achieved in two ways: by converting solar energy into heat and converting solar radiation into electricity.

Most renewable energy sources come directly or indirectly from the sun's energy that continuously radiates to the surface of the Earth. Direct collection of solar energy is done by:

Photovoltaic cells for electricity generation (photovoltaic - converting solar radiation to electricity), solar collectors for water heating (solar energy), mirrors for focusing sunlight (a solar energy plant).

Currently, most solar installations in Serbia are used to heat water and space in residential and commercial buildings. The intensity of sun radiation in Serbia is among the largest in Europe (Prvulovic and Ozegovic, 2009; Lambic, 1998).

Photovoltaic solar cells in Serbia can be used wherever there is a need for electricity: for lighting in private households, street lighting, operation of irrigation pumps, operation of audiovisual and refrigerating devices, operation of signaling devices on roads, operation of automats in parking spaces, operation of telecommunication devices and systems, etc.

\section{Solar collectors - Converting solar energy to heat}

There are several reasons for the application of solar energy (solar collectors), which are:

- over 55\% of total energy is consumed in households in Serbia in the form of electricity, of which a good part for heating sanitary consumption water (Lambic et al., 2010; Tolmac et al., 2014a).

- cost reduction is achieved for heating sanitary water for about 60 to $70 \%$ during the year, which leads to the unloading of the home budget,

- increased employment in the process of research, production, installation and servicing of solar equipment.

Solar energy as a source of energy for heating and hot water preparation has the following advantages:

- free and accessible everywhere,

- ecologically clean (no combustion, and emission of harmful gases such as $\mathrm{CO}_{2}, \mathrm{SO}_{2}$, $\mathrm{NO}_{2}$, etc.),

- it belongs to renewable energy sources (RES), so resources cannot be depleted (unlike coal, oil and gas),

- combined with conventional energy sources, it increases the energy efficiency of the plant. 


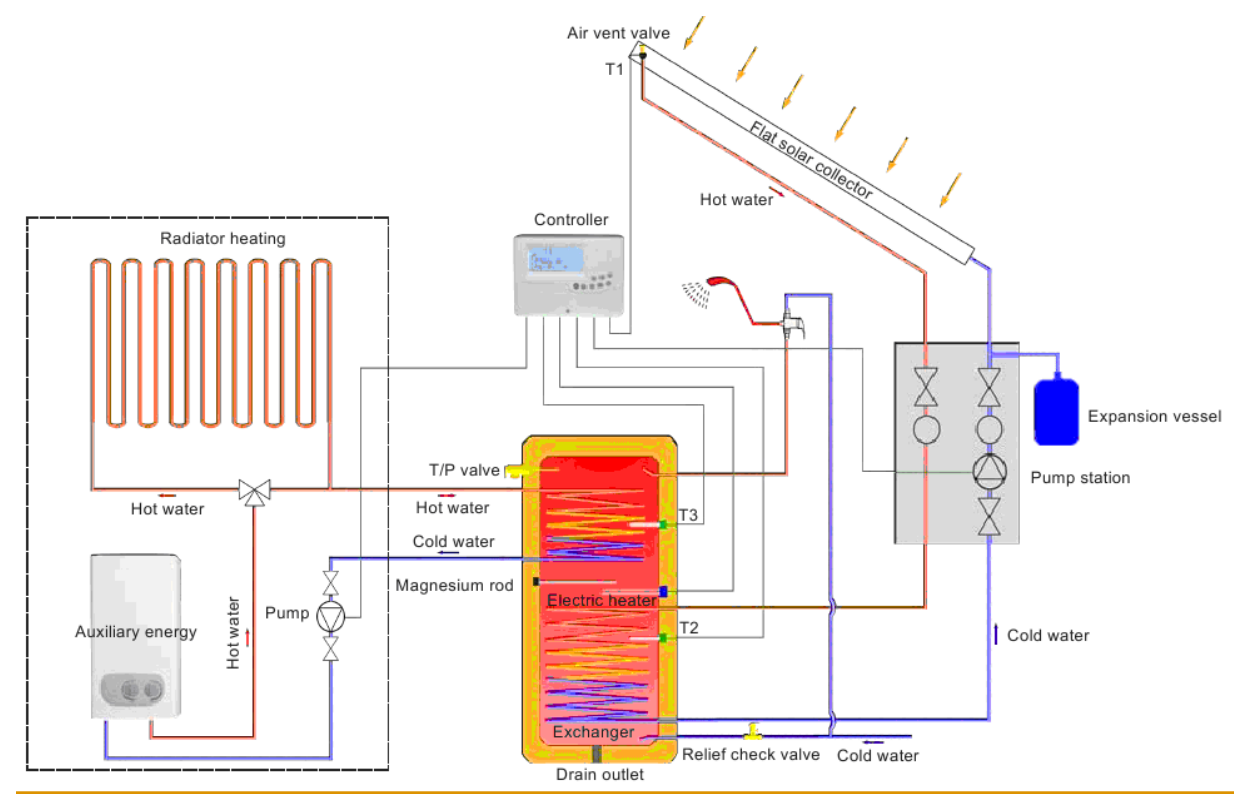

Figure 1. Schematic view of solar heating

As an inevitable precondition for the development of solar energy utilization in our country, it is necessary to direct and finance domestic knowledge in the field of heat conversion of solar radiation in order to achieve appropriate results in the area of:

- reducing energy dependence,

- increasing the employment of the population,

- reducing family costs for energy products,

- reducing pollution of our environment, etc.

In the climatic conditions of Serbia, the use of solar technologies is combined with other sources of heating in order to provide sufficient amount of heat in conditions of lower insolation or absence of insolation (in the evening, in the morning, in the night, in the winter, etc.). Water for heating needs, heated by solar collectors can also be used in central heating systems or central heat supply. Solar energy can cover 50-70\% of annual energy needs for heating water in households, in summer period and in transit periods, while in winter it is sufficient for pre-heating cold water.

\section{The potential of solar energy and its use}

The number of sunny days in Serbia is over 2000 hours. This is considerably more than in the European countries that prevail in the use of Sun energy. However, the solar potential is completely unused. In our conditions, solar collectors have become popular in households for water heating. The smallest collectors have a surface area of two square meters and are sufficient to heat water in one household.

The potential of solar energy represents $16.7 \%$ of the total utilized potential of RES in Serbia. The energy potential of solar radiation is about $30 \%$ higher in Serbia than in Central 
Analysis of the development...

Europe, and the intensity of solar radiation is among the largest in Europe. The average daily energy of global radiation on a flat surface during the winter period ranges between $1.1 \mathrm{kWh} \cdot \mathrm{m}^{-2}$ in the north and $1.7 \mathrm{kWh} \cdot \mathrm{m}^{-2}$ in the south, and during the summer period between $5.4 \mathrm{kWh} \cdot \mathrm{m}^{-2}$ in the north and $6.9 \mathrm{kWh} \cdot \mathrm{m}^{-2}$ in the south (Prvulovic et al., 2016a, 2018).

The average daily energies of global radiation on the horizontal surface in Serbia are given in Figure 2, according to (Lambic, 1998, 2004, Lambic et. al., 2006; Lambic and Tolmac, 2004).

All these data clearly show that Serbia has the resources of solar energy radiation well above the European average with an exceptionally favorable seasonal schedule and that its efficient and long-term use is necessary to be designed in the shortest period of time.

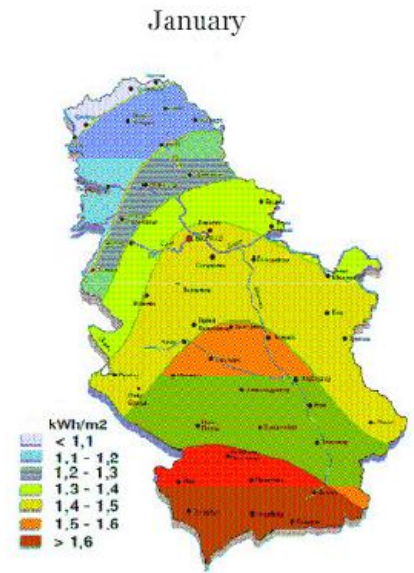

a)

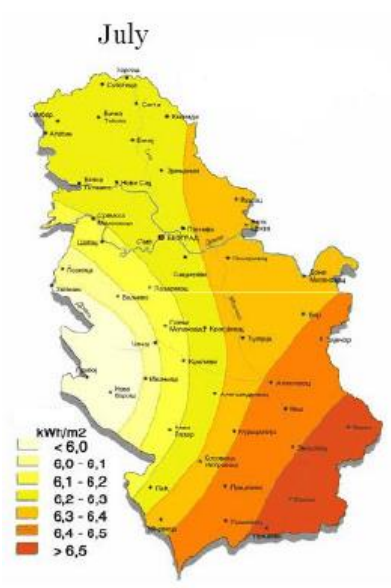

b)

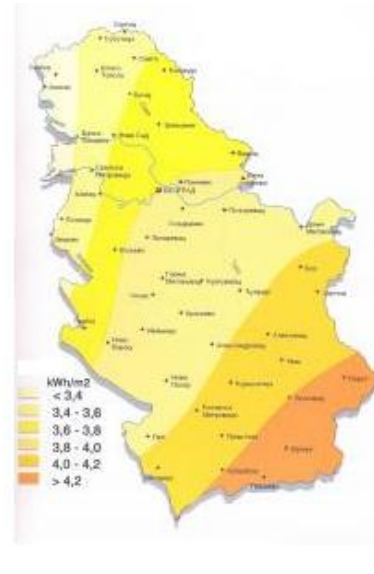

c)

Figure 2.
a)

Average daily energy of global radiation on the horizontal surface in January

b) Average daily energy of global radiation on the horizontal surface in July

c) Annual average daily energy of global radiation on a horizontal surface

The use of solar energy is a good way to reduce power consumption wherever possible. Although the price of investment in solar installation is relatively high, about 2000 euros per kilowatt of installed power $\left(2000 \mathrm{Eur} \cdot \mathrm{kW}^{-1}\right)$, it is worth investing in a secure market.

\section{Development possibilities of solar systems}

The energy potential is satisfactory throughout the whole territory of Serbia, which enables efficient use of thermal and photovoltaic effect of solar radiation. The use of thermal 
solar collectors is economical and can be applied from individual users to larger systems. Economic and environmental reasons lead to investment in research and development projects that, with their results, are investing in the production of equipment for the exploitation of energy.

There are important reasons why Serbia and Vojvodina should engage all available potentials to significantly increase the use of solar energy in a very short period. This would ensure an increase in employment in the segment of research, production, installation and servicing of equipment for the use of solar energy.

In October 2015 in Kikinda, Serbia, the first phase of the solar power plant was built. Solar parks have been the most active in Serbia from all renewable sources and 8.5 MW of these investments have been implemented since the planned 10 MW. Serbia has 91 facilities of this type, of which there are 8 solar parks on ground. This one in the Kikinda is one of the largest and the second largest in Vojvodina and the fourth in Serbia. The value of the solar power plant in Kikinda, Serbia, when it is completed will be about 1.3 million euros, and the power will be $1 \mathrm{MW}$. The incentive purchase price of electricity from solar energy is on average 20 eurocent $\cdot \mathrm{kWh}^{-1}$ (Prvulovic et al., 2016b).

By using solar energy in Serbia, significant energy savings and reduce of carbon dioxide emissions could be achieved. It would most effectively be used in the tourism and health sector and in households for water heating.

In climatic conditions in Belgrade, a $0.5 \mathrm{~m}^{2}$ solar collector per household member can heat up to $30 \%$ of the required consumable sanitary hot water per year. Considering that Serbia has 2.65 million housing units, if $4 \mathrm{~m}^{2}$ of solar collectors are installed on each of them, annually about $7420 \mathrm{GWh}$ of electricity will be saved, worth about 370 million euros, according to the data of the Agency for Energy Efficiency.

Unofficial data indicate that about $15000 \mathrm{~m}^{2}$ of solar collectors are installed annually in Serbia, which is little considering the potential. The application of solar energy is a good, justified and economical way to reduce conventional energy consumption wherever possible. This means that even though the costs of investing in the photovoltaic systems for electricity production are still relatively large (around 2000 euros per $1 \mathrm{~kW}$ of installed power), it is worthwhile to invest in, as the investment will in any case pay off.

\section{Cost-effectiveness use of Renewable Energy Sources}

If we observe the listed average purchase prices for renewable energy sources in Table 1 , it can be clearly seen that the most worthwhile is investing in small hydroelectric power plants.

Table 1.

Average purchase prices of electricity produced from renewable energy sources, according to (Prvulovic et al., 2018).

\begin{tabular}{lcc}
\hline \multicolumn{1}{c}{ Type of power plant } & $\begin{array}{c}\text { The price of the installed power } \\
\left(\text { Euro } \cdot \mathrm{kW}^{-1}\right)\end{array}$ & $\begin{array}{c}\text { Average purchase price } \\
\left(\text { eurocent } \cdot \mathrm{kWh}^{-1}\right)\end{array}$ \\
\hline Small hydroelectric power plants & 2000 & 9 \\
Wind power plants & 1000 & 9.5 \\
Solar power plants & 2000 & 20 \\
\hline
\end{tabular}


Analysis of the development...

Of course, at this moment, it is justified for Serbia to encourage the use and energy of solar radiation to produce heat and electricity in the domain of households, industry and some branches of agriculture. Such a policy would be useful for the development of the domestic economy as well as the employment of the population in the field of clean energy. In a long-term, the future of converting solar radiation is in thermal and FV technologies and their integration with other branches of technologies.

\section{Conclusion}

The economic situation in the country's economy, the technological state of energy and production technologies and the structure of available energy sources, condition the economic effectiveness and energy efficiency of energy use in Serbia. As a result of the steady increase in the price of fossil fuels, and especially oil, research in the field of renewable energy sources has been intensifying lately. Renewable energy sources and their energy potential, such as solar energy, should be considered in order to meet the needs of consumers. Researches show that Serbia is a country with a high RES potential and that it has favorable conditions to produce electrical and heat energy from renewable sources. Energy supply from renewable energy sources is a key factor for each country's strategy, because it directly contributes to reducing the negative effect on the environment.

\section{References}

Grbic, N., Smiljkovic, A., Stefanovic, S. (2008). Causes and consequences of global warming - renewable energy sources in the function of reducing the emission of harmful gases. Energetics Technologies, 5, 1-2, 56-59.

Lambic, M. (1998). Thermotechnics with energetics. Technical Faculty "Mihajlo Pupin", Zrenjanin, Serbia.

Lambic, M. (2004). Solar Technique, Solar Energy Society. Serbia Solar, Zrenjanin, Serbia.

Lambic, M. (2011). Contribution to the reduction of pollution of the environment. Energetics Technologies, 8, 1, 3-9.

Lambic, M., Hornjak, N., Takaric, A. (2010). Experience in the use of solar energy in practice. Energetics Technologies, 7, 4, 23-30.

Lambic, M., Pavlovic N., Tasic I., Stojicevic D. (2006). Solar Energetics. Serbia Solar, Zrenjanin, Serbia.

Lambic, M., Tolmac, D. (2004). Energetic efficiency - management, rational consumption, efficiency. Serbia Solar, Zrenjanin, Serbia.

Markovic, S., Krstic, M., Bojkovic, R., Djordjevic, Lj. (2009). Management as a factor of intensifying the application of renewable energy sources. IMK-14 - Research and developmen, 15, 1-2, 121-128.

Prvulovic, N., Ozegovic, L. (2009). Renewable energy sources of Serbia - future or delusion. Energetics Technologies, 6, 3-4, 36-42.

Prvulovic, S., Josimovic, Lj., Matic, M., Tolmac, D., Radovanovic, Lj. (2016a). Resource potential and scope of the use of renewable energy sources in Serbia, Energy Sources Part B-Economics Planning and Policy, 11, 901-910.

Prvulovic, S., Lambic, M., Matic, M., Tolmac, D., Radovanovic, Lj., Josimovic, Lj. (2016b). Solar energy in Vojvodina (Serbia): Potential, scope of use, and development perspective. Energy Sources Part B-Economics Planning and Policy, 11, 12, 1111-1117. 
Prvulovic, S., Tolmac, D. (2013). Global use of renewable energy in rural areas. Energetics Technologies, 10, 1, 63-66.

Prvulovic, S., Tolmac, D., Blagojevic, Z. (2009). Global Energy Perspectives. Energetics Technologies, 6, 2, 9-15,

Prvulovic, S., Tolmac, D., Caleta, R. (2012). Overview of the use of renewable energy sources on a global scale. Thermotechnics, 38, 1, 35-45.

Prvulovic, S., Tolmac, D., Matic M., Radovanovic, Lj., Lambic M. (2018). Some aspects of the use of solar energy in Serbia, Energy Sources Part B-Economics Planning and Policy, vol. 13, no. 4, pp. 237-245, 2018.

Tolmac, D., Prvulovic, S., Tolmac, J. (2014a). Rationalization of energy consumption in industry. Technical Faculty "Mihajlo Pupin", Zrenjanin, Serbia.

Tolmac, D., Prvulovic, S., Tolmac, J. (2014b). Process systems and plants. Technical Faculty "Mihajlo Pupin”, Zrenjanin, Serbia.

\section{ANALIZA MOŻLIWOŚCI ROZWOJU SYSTEMÓW SOLARYCH W SERBII}

Streszczenie. Niniejsza praca przedstawia analizę możliwości rozwoju systemów solarnych w Republice Serbii. Należy wziąć pod uwagę odnawialne źródła energii i ich potencjał energetyczny, taki jak energia słoneczna by sprostać potrzebom konsumentów. Energię słoneczną można uznać za najnowocześniejszą energię odnawialną, stopień użycia której ciągle wzrasta. Naukowcy wskazują, że Serbia jest krajem z wysokim potencjałem i posiada korzystne warunki do produkcji energii elektrycznej i ciepła z odnawialnych źródeł. Praca ta ma na celu przedstawić możliwości zastosowania energii słonecznej w Serbii. Dostarczanie energii z odnawialnych źródeł jest kluczowym czynnikiem dla strategii każdego kraju, ponieważ bezpośrednio wpływa na zmniejszenie negatywnego wpływu na środowisko.

Słowa kluczowe: słońce, odnawialne źródła energii, energia słoneczna, potencjał słoneczny, promieniowanie słoneczne 